\title{
PENGEMBANGAN BAHAN AJAR BERBASIS E LEARNING PADA MATAKULIAH EVALUASI PEMBELAJARAN UNTUK MENINGKATKAN HASIL BELAJAR MAHASISWA
}

\author{
Yeni Rahmawati, ES. ${ }^{1)}$, Ira Vahlia ${ }^{2)}$ \\ 1)2) Pendidikan Matematika FKIP Universitas Muhammadiyah Metro \\ E-mail: yeni.rahmawati1988@yahoo.com ${ }^{1)}$, iravahlia768@yahoo.co.id ${ }^{2)}$
}

\begin{abstract}
The ability to evaluate learning is a basic skill that must be mastered by students as prospective teachers. Based on this, it is necessary a teaching materials that help students and lecturers during the lecture. Students can know and understand about learning evaluation. In addition, the existence of teaching materials can help students to improve students' skills in understanding the material. In order for students to learn independently and adapt to technology, e-learning is needed based on teaching materials where lecturers do not have to guide students one by one, but the students can also help each other with the help of internet. The research was conducted at Muhammadiyah University of Metro and the subject of the research was 6th semester students consisting of 2 classes. Class $A$ as an experimental class whereas class $B$ as control class. The development of e-learning-based teaching materials uses the main 4$D$ development model of Define, Design, Develop, and Disseminate or adapted into 4-P model, defining, designing, developing, and deploying. The results of this study indicate that: 1) Teaching materials based on e-learning can support lecturing evaluation of learning in mathematics education program. This can be seen from the percentage of student response questionnaires of $80 \%$ that fulfill the criteria is quite valid; 2). Teaching materials based on e-learning can optimize student learning outcomes. This can be shown in student learning outcomes that achieve optimal learning outcomes of $87.5 \%$
\end{abstract}

Keywords: development, e-learning, evaluation of learning, learning materials

\section{PENDAHULUAN}

Mata kuliah wajib yang harus ditempuh mahasiswa pendidikan matematika salah satunya adalah evaluasi proses dan hasil belajar (yang selanjutnya disebut evaluasi pembelajaran). Mata kuliah ini mempelajari berbagai hal yang berkaitan dengan teknik penilaian baik selama proses pembelajaran maupun di akhir pembelajaran, misalnya menyusun kisi-kisi soal dan analisis butir soal. Kemampuan melakukan evaluasi pembelajaran merupakan kemampuan dasar yang harus dikuasai oleh para mahasiswa sebagai calon guru.

Menurut Hao Shi (2010) pengembangan bahan ajar dimaksudkan untuk memberikan pembelajaran konteks di mana mahasiswa dapat merefleksikan materi baru, membahas pemahaman tentatif mereka dengan orang lain,aktif mencari informasi baru, mengembangkan keterampilan dalam komunikasi dan kolaborasi, dan membangun koneksi konseptual untuk basis pengetahuan yang sudah ada. 
Saya sebagai dosen pengampu mata kuliah evaluasi pembelajaran menemukan beberapa hal diantaranya:

1. Sudah terdapat handout mata kuliah evaluasi pembelajaran, namun dari tahun 2005 belum pernah direvisi bahkan materinya sudah tidak sesuai lagi dengan perkembangan evaluasi yang sekarang.

2. Masih banyak mahasiswa yang bingung dalam menentukan nilai reliabilitas serta bingung menentukan masuk dalam kategori sangat rendah, rendah, sedang, tinggi, atau sangat tinggi.

3. Mahasiswa belum dapat secara aktif tanpa disuruh oleh dosennya mencari sumber selain dari handout yang diberikan oleh dosen.

4. Kebanyakan mahasiswa memiliki handphone android dan laptop sehingga dapat dengan mudah mengakses internet. Namun belum dapat digunakan maksimal dalam pembelajaran perkuliahan.

5. Pada saat mahasiswa semester 7, banyak mahasiswa yang masih mengalami kesulitan dalam mengolah data hasil belajar yang sebenarnya pada saat penelitian karena keterbatasan waktu yang tersedia pada perkuliahan evaluasi pembelajaran di semester 5 .

6. Belum adanya bahan ajar mata kuliah evaluasi pembelajaran yang memiliki standar jurusan FKIP Universitas Muhammadiyah Metro yang dapat dipakai oleh mahasiswa matematika serta dapat dipakai juga oleh mahasiswa prodi lainnya.

7. Rata-rata hasil belajar mahasiswa masih rendah yaitu < 65 sehigga perlu adanya cara dari dosen dalam meningkatkan hasil belajar mahasiswa.

Berdasarkan hal tersebut, maka diperlukan suatu bahan ajar sehingga membantu mahasiswa dan dosen selama proses perkuliahan. Mahasiswa dapat mengetahui dan memahami tentang evaluasi pembelajaran. Selain itu, dengan adanya bahan ajar dapat membantu mahasiswa untuk meningkatkan kemampuan mahasiswa dalam memahami materi. Supaya mahasiswa dapat belajar secara mandiri dan menyesuaikan dengan teknologi diperlukan bahan ajar berbasis $e$ learningdimana dosen tidak harus membimbing mahasiswa satu persatu, namun sesama mahasiswa juga dapat saling membantu. Menurut Matsuda (2016) bahan ajar e-learning yang dikembangkan harus memberikan kepercayaan diri berpikir mahasiswa, "Aku bisa melakukannya". Dosendapat membimbing mahasiswa dan memberitahukan prosedur dalam proses e-learning

Muhaimin (2009) mengungkapkan bahwa "bahan ajar adalah segala bentuk bahan yang digunakan untuk membantu guru/instruktur dalam melaksanakan kegiatan pembelajaran. Sedangkan menurut Majid (2007) "bahan ajar adalah segala bentuk bahan, informasi, alat dan teks yang digunakan untuk membantu guru/ instruktur dalam melaksanakan kegiatan belajar mengajar. Bahan yang dimaksud bisa berupa tertulis maupun bahan yang tidak tertulis".

Dari beberapa pendapat diatas, pengembangan bahan ajar adalah proses pemilihan, adaptasi, dan pembuatan bahan ajar berdasarkan kerangka acuan tertentu serta didasarkan pada analisis kebutuhan mahasiswa. Sehingga bermanfaat bagi mahasiswa untuk menguasai kompetensi tertentu, karena bahan ajar dapat membantu mahasiswa menambah informasi tentang materi yang dipelajari melalui kegiatan pembelajaran secara sistematis. 
Bahan ajar berbasis e-learning juga sebagai pengganti fungsi dosen dikarenakan mahasiswa dapat saling sharing di sosial media, baik dalam bentuk aplikasi schoology maupun web. Jadi jika dosen mempunyai fungsi menjelaskan sesuatu, maka bahan ajar berbasis e-learning harus mampu memperjelas sesuatu dengan bahasa yang mudah diterima mahasiswa seperti halnya dosen. E-learning membuat pembelajaran dapat lebih terbuka dan fleksibel. Pembelajaran dapat terjadi kapan saja, dimana saja, dan dengan siapa saja.

Tujuan dari penelitian pengembangan ini yaitu: 1) Bahan ajar berbasis $e$ learning dapat menunjang perkuliahan evaluasi pembelajaran. 2) Bahan ajar berbasis e-learning dapat mengoptimalkan hasil belajar mahasiswa. 3) Mendeskripsikan keefektifan media pembelajaran $e$ learning dengan schoology dalam mata kuliah evaluasi pembelajaran.

\section{METODE PENELITIAN}

Menurut Bock dalam "Getting It Right : R\&D Methods in Science and Engineering" dalam bukunya Putra (2012) menjelaskan pengertian pengembangan: "Development is a process that applies knowledge to create new device on effects".

Menurut Trianto (2010) "model pengembangan 4-D tahap utama yaitu Define, Design, Develop, dan Disseminate atau diadaptasikan menjadi model 4-P, yaitu pendefinisian, perancangan, pengembangan, dan penyebaran".

\section{Lokasi Penelitian}

Penelitian dilaksanakan di Universitas Muhammadiyah Metro. Subjek penelitian adalah mahasiswa semester 6 yang terdiri dari 2 kelas.
Kelas A untuk kelas eksperimen. Kelas B untuk kelas kontrol.

\section{Peubah yang Diamati/Diukur,}

Dalam penelitian ini, peubah yang diamati adalah bahan ajar berbasis e-learning pada mata kuliah evaluasi pembelajaran program studi pendidikan matematika.

\section{Model Yang Digunakan}

Jenis penelitian ini adalah penelitian pengembangan (Research and Development) yaitu jenis penelitian yang mengembangkan suatu produk baru atau menyempurnakan produk yang telah ada sebelumnya. Penelitian pengembangan ini mengacu pada model pengembangan bahan ajar 4-D (four-D Model) yang terdiri dari empat tahapan yaitu tahap pendefinisian (define), tahap perancangan (design), tahap pengembangan (develop), dan tahap penyebaran (disseminate). Model pengembangan 4-D ini digunakan karena tahapan penelitian pengembangan 4-D memiliki kelebihan, yaitu dalam model 4-D melibatkan analisis materi dan analisis tugas dalam menentukan tujuan pembelajaran khusus, sehingga akan memudahkan dalam menjabarkan tujuan pembelajaran umum ke tujuan pembelajaran khusus. Pada penelitian ini hanya sampai pada tahap pengembangan (develop).

\section{Rancangan Penelitian}

\begin{tabular}{llr}
\multicolumn{2}{c}{ Penelitian } & \multicolumn{2}{c}{ pengembangan } \\
meliputi : 1) & penelitian & dan \\
pengumpulan & informasi, & 2 ) \\
perencanaan, & 3) & pengembangan \\
produk, 4) uji coba awal, 5) revisi \\
produk, 6) uji coba lapangan, 7) revisi \\
produk uji coba lapangan, 8) uji coba \\
operasional produk, 9) revisi produk \\
dan 10) implementasi dan desiminasi.
\end{tabular}


Semua langkah diatas akan dicakup dalam pengembangan produk dan validasi produk yang mengacu pada pendapat Borg \& Gall pada penelitian ini cukup menggunakan langkah 1 sampai 7 yang juga sudah diadaptasi sesuai dengan keperluan penelitian ini. Dari skema pengembahan bahan ajar, saat ini bahan ajar sudah pada tahap hasil validasi ahli.

\section{Teknik Pengumpulan Data}

Data dalam penelitian ini adalah informasi tentang efektivitas bahan ajar berbasis e-learning yang di dapat dari angket respon mahasiswa. Berikut langkah-langkah untuk mendapatkan data penelitian:

a. Menyiapkan bahan ajar b. Memvalidasi bahan ajar. Bahan ajar akan divalidasi oleh 3 orang validator.

c. Merevisi bahan ajar yang didapat dari validator.

d. Menguji coba bahan ajar kepada mahasiswa.

e. Memberikan angket respon mahasiswa.

f. Merivisi bahan ajar berdasarkan hasil angket mahasiswa.

g. Mencetak bahan ajar.

\section{Analisis Data}

Tahap ini dilaksanakan setelah didapatkan data dari angket yang diisi oleh 3 validator yang terdiri dari 2 ahli materi matematika dan 1 ahli bahasa.

Tabel 1 Kriteria Jawaban Item Instrumen Validasi Beserta Skornya

\begin{tabular}{|c|c|c|}
\hline No & Jawaban & Skor \\
\hline 1 & Sangat baik & 4 \\
\hline 2 & Cukup baik & 3 \\
\hline 3 & Kurang baik & 2 \\
\hline 4 & Tidak baik & 1 \\
\hline
\end{tabular}

Kemudian data dianalisis secara deskriptif kuantitatif, yaitu menghitung persentase skor bahan ajar yang dikembangkan

Persentase Skor $=\frac{\text { Jumlah Skor per indikator }}{\text { Jumlah Skor Maks.Indikator }} \times 100 \%$

Dari hasil perhitungan menggunakan rumus di atas, dihasilkan angka dalam bentuk persen. Klasifikasi skor tersebut kemudian ditafsir dengan kalimat bersifat kualitatif yang tercantum dalam tabel berikut ini:

Tabel 2 Kriteria Persentase Indikator Bahan Ajar (Akbar, 2013: 155)

\begin{tabular}{|l|c|}
\hline \multicolumn{1}{|c|}{ Kriteria Validitas } & Tingkat Validitas \\
\hline Sangat valid, atau dapat digunakan tanpa revisi & $85 \%<\mathrm{X} \leq 100 \%$ \\
\hline Cukup valid, atau dapat digunakan dengan revisi kecil & $70 \%<\mathrm{X} \leq 85 \%$ \\
\hline $\begin{array}{l}\text { Kurang valid, disarankan tidak dipergunakan karena } \\
\text { perlu revisi besar }\end{array}$ & $50 \%<\mathrm{X} \leq 70 \%$ \\
\hline Tidak valid, atau tidak boleh dipergunakan & $0 \%<\mathrm{X} \leq 50 \%$ \\
\hline
\end{tabular}

Bahan ajar dikatakan baik dan layak digunakan jika dinyatakan valid oleh validator dengan rata rata kriteria minimal "Cukup Valid". Berdasarkan hasil validasi dari angket didapatkan kriteria persentase bahan ajar sebesar $80 \%$ dan masuk dalam kriteria cukup valid. 


\section{Indikator Capaian Hasil Penelitian}

Indikator capaian hasil penelitian ini adalah:

1. Bahan ajar berbasis e-learning dapat menunjang pembelajaran mahasiswapada mata kuliah evaluasi pembelajaran.

2. Mahasiswa yang mendapatkan hasil belajar optimal dengan menggunakan bahan ajar berbasis e-learning mencapai $\geq 75 \%$.

\section{HASIL DAN PEMBAHASAN}

Pengembangan bahan ajar evaluasi pembelajaran berbasis e-learning ini di mulai pada hari Senin, tanggal 13
Februari 2017 dengan cara menyebar angket kepada mahasiswa yang pernah mengikuti perkuliahan evaluasi pembelajaran. Selanjutnya, pada hari rabu tanggal 15 Februari 2017 dilakukan analisis terhadap hasil angket.

\section{a. Hasil Angket Awal Mahasiswa}

Berdasarkan hasil angket tersebut, diperoleh informasi bahwa bahan ajar yang digunakan cukup baik dan perlu penyempurnaan dalam penyusunan bahan ajar. Hal ini ditunjukkan pada sampel hasil angket mahasiswa pada Gambar 1

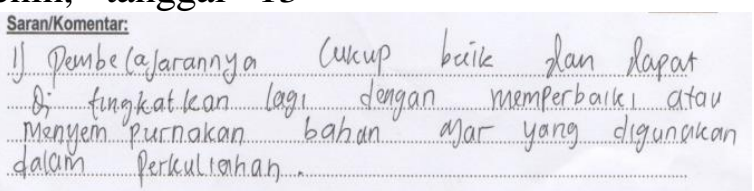

Gambar 1 Sampel Hasil Angket Awal Mahasiswa

\section{b. Hasil Validasi Bahan Ajar}

Setelah dilakukan penyebaran angket, langkah selanjutnya melakukan validasi bahan ajar dan tes hasil belajar. Validasi dilakukan oleh: 1)Bapak Nurain Suryadinata, M. Pd. Dosen Pendidikan Matematika Universitas Muhammadiyah Metro, 2) Bapak Nego Linuhung, M. Pd. Dosen Pendidikan Matematika Universitas Muhammadiyah Metro, 3) Ibu Rina
Agustina, M. Pd. Dosen Pendidikan Matematika Universitas Muhammadiyah Metro yang terdiri dari validasi bahasa, desain dan materi bahan ajar yang mengalami beberapa revisi dari ketiga dosen tersebut.

Pada hari senin tanggal 20 Februari 2017, bahan ajar dan tes hasil belajar telah selesai divalidasi. Berdasarkan hasil validasi didapatkan, data berikut:

Tabel 3 Nilai Hasil Validasi Bahan Ajar

\begin{tabular}{|c|c|c|c|}
\hline No & Nama & Nilai & Kategori \\
\hline 1 & Nurain Suryadinata, M. Pd & $86,5 \%$ & Sangat Valid \\
\hline 2 & Nego Linuhung, M. Pd. & $88,6 \%$ & Sangat Valid \\
\hline 3 & Ibu Rina Agustina, M. Pd. & $90 \%$ & Sangat Valid \\
\hline \multicolumn{2}{|c|}{ RATA-RATA } & $\mathbf{8 8 , 3 6 \%}$ & Sangat Valid \\
\hline
\end{tabular}

Berdasarkan Tabel 3, dapat terlihat bahwa nilai validasi bahan ajar yang diperoleh dari validator 1 sebesar $86,5 \%$, validator 2 sebesar $88,6 \%$, valiadator 3 sebesar $90 \%$. Sehingga berdasarkan nilai dari 3 validator tersebut, dapat diambil rata-rata nilai validasi bahan ajar sebesar $88,36 \%$ dan memenuhi kriteria sangat valid. Dari hasil validasi tersebut, maka bahan ajar berbasis e-learning ini telah siap untuk di uji coba dan digunakan pada 
mahasiswa dalam perkuliahan evaluasi pembelajaran.

Tabel 4 Nilai Hasil Validasi Tes HasilBelajar

\begin{tabular}{|c|l|c|c|}
\hline No & \multicolumn{1}{|c|}{ Nama } & Nilai & Kategori \\
\hline 1 & Nurain Suryadinata, M. Pd & $84,5 \%$ & Sangat Layak \\
\hline 2 & Nego Linuhung, M. Pd. & $73,5 \%$ & Layak \\
\hline 3 & Ibu Rina Agustina, M. Pd. & $73 \%$ & Layak \\
\hline & RATA-RATA & $\mathbf{7 7 \%}$ & Layak \\
\hline
\end{tabular}

Berdasarkan Tabel 4, dapat terlihat bahwa nilai validasi tes hasil belajar yang diperoleh dari validator 1 sebesar $84,5 \%$, validator 2 sebesar $73,5 \%$, valiadator 3 sebesar 73\%. Sehingga berdasarkan nilai dari 3 validator tersebut, dapat diambil rata-rata nilai validasi tes hasil belajar sebesar $77 \%$ dan memenuhi kriteria layak. Dari hasil validasi tersebut, maka tes hasil belajar evaluasi ini telah siap untuk di uji coba dan digunakan pada mahasiswa dalam perkuliahan evaluasi pembelajaran.

\section{c. Hasil Uji Coba Kelompok Kecil}

Pada hari senin tanggal 27 Februari 2017 di lakukan uji coba kelompok kecil pada mahasiswa semester delapan yang pernah menerima materi perkuliahan evaluasi pembelajaran sebanyak 5 orang. Berdasarkan hasil uji coba kelompok kecil diperoleh sampel komentar dari mahasiswa yang dapat ditunjukkan pada Gambar 2.

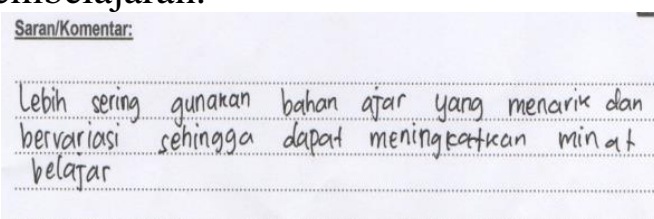

\section{Gambar 2 Komentar Mahasiswa Pada Uji Coba Kelompok Kecil}

\section{d. Hasil Ujicoba Kelompok Besar}

Setelah dilakukan revisi hasil dari uji coba kelompok kecil, selanjutnya bahan ajar dapat di gunakan pada uji coba kelompok besar. Dalam hal ini kelompok besar adalah mahasiswa semester 6 yang menjadi subyek penelitian sebanyak 10 orang. Uji coba kelompok besar di laksanakan pada hari Kamis Tanggal 2 Maret 2017. Berdasarkan hasil uji coba kelompok besar didapatkan sampel komentar dari mahasiswa yang dapat ditunjukkan pada Gambar 3.

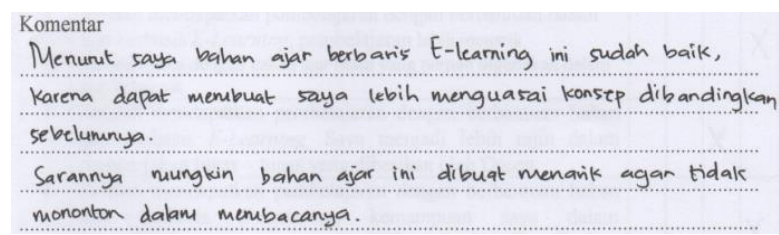

Gambar 3 Komentar Mahasiswa Pada Uji Coba Kelompok Besar

\section{e. Pembelajaran Menggunakan $E$ - Learning}

Setelah melakukan uji coba kelompok besar, maka langkah selanjutnya ialah penggunaan bahan ajar berbasis e-learning dengan aplikasi schoolgy dalam perkuliahan evaluasi pembelajaran. Langkah pembelajaran 
berbasis e-learning yaitu mahasiswa dan dosen membuat akun pada aplikasi schoology. Kemudian dosen mengunggah materi, PowerPoint, tugas dan latihan kedalam aplikasi tersebut. Dosen memastikan semua mahasiswa mempunyai akun dan memberikan pelatihan untuk mahasiswa bagaimana cara menggunakan aplikasi berbasis schoology. Jumlah member yang telah bergabung dengan aplikasi schoology dapat ditunjukkan pada Gambar 4.

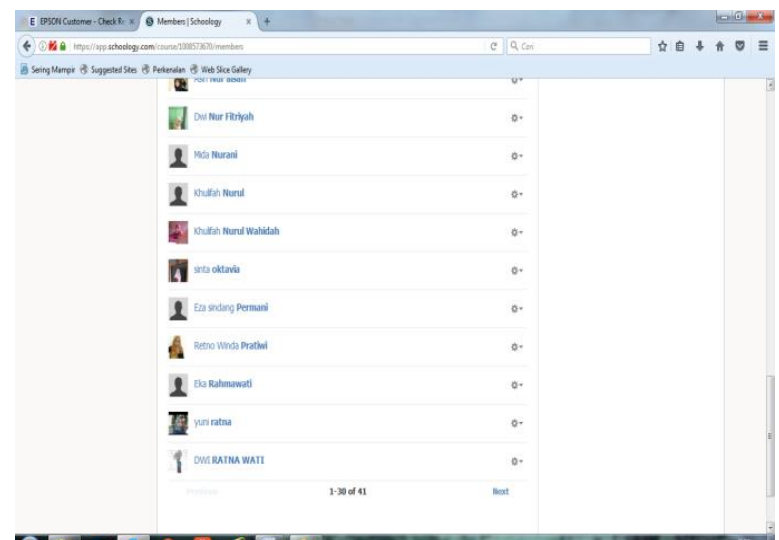

a日ger 4 Jumlah member pada aplikasi schoology

Perkuliahan di mulai hari Rabu memberikan tanggapan kedalam Tanggal 8 Maret 2017. Pada minggu diskusinya. Dengan pembelajaran $e$ pertama, mahasiswa sudah dapat learning ini, mahasiswa menjadi mengetahui RPS dosen dengan termotivasi mencari sumber lainnya mendownloadnya. Selain itu sudah bahkan jurnal terbaru. Adapun salah dapat mengetahui materi-materi yang satu kegiatan perkuliahan melalui $e$ terstruktur berhubungan dengan learning dapat ditunjukkan pada evaluasi pembelajaran. Banyak Gambar 5. mahasiswa yang bertanya bahkan

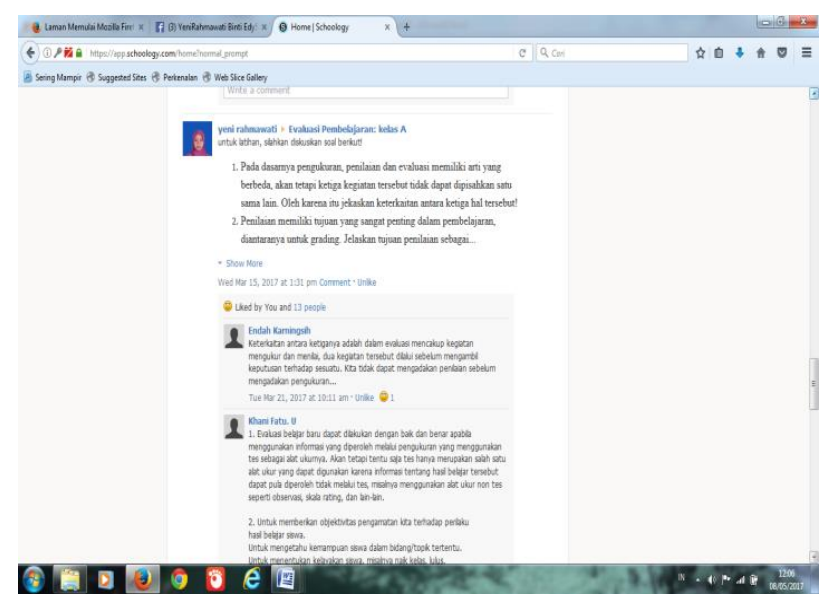

Gambar 5. Komentar mahasiswa terhadap pertanyaan dosen via schoology

\section{f. Uji Efektivitas Bahan Ajar}

Selanjutnya, diuji efektivitas penggunaan bahan ajar berbasis $e$ learning ini yang dilaksanakan pada hari Selasa, 25 April 2017. Untuk pengujian efektivitas bahan ajar berbasis e-learning ini menggunakan kelas A sebagai kelas eksperimen yang terdiri dari 40 orang mahasiswa. Sedangkan yang menjadi kelas kontrol 
adalah kelas B yang terdiri dari 32 orang mahasiswa.
Berdasarkan hasil tes diperoleh hasil seperti yang tertera pada Tabel 5 dan 6 berikut:

Tabel 5. Nilai Rata-rata Mahasiswa pada Penggunaan Bahan Ajar berbasis E-learning

\begin{tabular}{|c|c|}
\hline Kelas & Nilai Rata-rata \\
\hline A (Eksperimen) & 79 \\
\hline B (Kontrol) & 68,21 \\
\hline
\end{tabular}

Tabel 6. Hasil Uji Efektivitas Penggunaan Bahan Ajar berbasis E-learning

\begin{tabular}{|l|c|c|}
\hline Kelas & Kelas A & Kelas B \\
\hline $\mathrm{N}$ & 40 & 32 \\
\hline $\bar{x}$ & 79 & 68,21 \\
\hline Varians & 30,15 & 32,05 \\
\hline Standar deviasi & 5,49 & 5,66 \\
\hline
\end{tabular}

$$
\begin{array}{ll}
t_{\text {hit }} & =13,9 \\
t_{\text {tabel }} & =1,99
\end{array}
$$

Karena $t_{\text {hitung }}>t_{\text {tabel }}$ maka Ho ditolak dapat disimpulkan bahwa terjadi perbedaan rata-rata hasil belajar mahasiswa pada kelas yang menggunakan bahan ajar evaluasi pembelajaran berbasis e-learning. Dari tabel tersebut, dapat terlihatbahwa kelas A sebagai kelas eksperimen memiliki nilai rata-rata sebesar 79 yang lebih tinggi dibandingkan kelas $\mathrm{B}$ yang memiliki rata-rata sebesar 68,21.

\section{KESIMPULAN DAN SARAN}

Berdasarkan hasil penggunaan bahan ajar evaluasi pembelajaran berbasis e-learning diperoleh kesimpulan, bahwa:

1. Bahan ajar berbasis e-learning dapat menunjang perkuliahan evaluasi pembelajaran. Hal ini dapat dilihat dari persentase angket respon mahasiswa sebesar $80 \%$ yang memenuh kriteria cukup valid.

2. Bahan ajar berbasis e-learning dapat mengoptimalkan hasil belajar mahasiswa. Hal ini dapat ditunjukkan pada hasil belajar mahasiswa yang mencapai hasil belajar optimal sebesar $87,5 \%$
Dari hasil penelitian yang diperoleh, maka diberikan saran kepada peneliti lain, sebaiknya menjelaskan petunjuk penggunaan Schoology dengan rinci dan jelas agar mahasiswa memahami langkah-langkah pengunaan Schoology sehingga pembelajaran dapat berlangsung dengan baik. Bagi mahasiswa sebaiknya membaca petunjuk penggunaan yang terdapat dalam Schoology secara cermat dan teliti, sehingga langkah-langkah pembelajaran dalam Schoology dapat berjalan dengan baik.

\section{DAFTAR PUSTAKA}

Akbar, S. 2013. Instrumen Perangkat Pembelajaran. Bandung: PT Remaja Rosdakarya

Hao Shi. 2010. Developing E-Learning Materials For Software Development Course. International Journal of Managing Information Technology. Vol 2 (No 2) Hal. 1621. Diunduh hari Senin tanggal 3 Oktober 2016 pukul 13.50 pada https://pdfs.semanticscholar.org/9 
ISSN 2089-8703 (Print) Vol. 6, No. 2 (2017)

ISSN 2442-5419 (Online)

472/e510ce89107e60cfd6131d5d. pdf

Majid, Abdul. 2007. Perencanaan Pembelajaran. Bandung: PT. Remaja Rosdakarya.

Muhaimin. 2009. Modul Wawasan Pengembangan Bahan Ajar bab $V$. Malang: LKP2-I.

Matsuda. 2016. Development And Evaluation Of The E-Learning Teaching Materials for surgical nursing training. US National Library. Vol 1 (No 3) Hal. 122123. Diunduh hari Senin tanggal 17 Oktober 2016 pukul 09.30 pada

https://www.ncbi.nlm.nih.gov/pub med/17102396.

Putra, Nusa. 2012. Research \& Development Penelitian dan Pengembangan. Jakarta: Raja Gravindo Persada.

Trianto. 2010. Mendesain Model Pembelajaran Inovatif-Progresif. Jakarta: Kencana Prenada Media Group. 